\title{
An urban regeneration "made-in-China": Chinese traders and market expansion in Budapest
}

Une régénération urbaine "made in China": les commerçants chinois et l'expansion des marchés de gros à Budapest

Renovación urbana "Made in China": comerciantes chinos y la expansión de los mercados mayoristas en Budapest

Ya-Han Chuang

\section{(2) OpenEdition}

Journals

Electronic version

URL: http://journals.openedition.org/mappemonde/4212

DOI: 10.4000/mappemonde.4212

ISSN: $1769-7298$

Publisher

UMR ESPACE

\section{Electronic reference}

Ya-Han Chuang, "An urban regeneration "made-in-China": Chinese traders and market expansion in Budapest », Mappemonde [Online], 128 | 2020, Online since 01 July 2020, connection on 10 December 2020. URL : http://journals.openedition.org/mappemonde/4212 ; DOI : https://doi.org/10.4000/ mappemonde.4212

This text was automatically generated on 10 December 2020.

\section{cc) (i) (2) (2)}

La revue Mappemonde est mise à disposition selon les termes de la Licence Creative Commons Attribution - Pas d'Utilisation Commerciale - Partage dans les Mêmes Conditions 4.0 International. 


\section{An urban regeneration "made-in- China": Chinese traders and market expansion in Budapest}

Une régénération urbaine "made in China ": les commerçants chinois et

l'expansion des marchés de gros à Budapest

Renovación urbana "Made in China": comerciantes chinos y la expansión de los

mercados mayoristas en Budapest

Ya-Han Chuang

\section{Introduction: Revisiting globalization and urban transformation by looking at post-socialist cities}

1 In the past decades, the global economic system experienced a dramatic transformation, marked by the deindustrialization of the European and North American economies in the 1970s and 1980s and the increasing involvement of China in world markets since the 1980's. The increasing influence of China's cheap labor force and global economic performance are manifestations of an uneven development within the world economic system. This period thus opens an era defined as "post-industrial" (Bell, 1973) or "post-Fordist" (Harvey, 1989a), characterized by the end of standardized production, the notion of flexible accumulation, and the compression of time and space requirements resulting from an increasingly global production network.

2 Scholarly discussion about the urban consequences of economic globalization and deindustrialization has mostly focused on the transformation of the housing market and the monetization of lands in advanced economies. Three approaches to the issue are most prominent: The first, mainly argued by geographers in the Marxist tradition, emphasizes the neo-liberalization of urban governance. David Harvey uses the term "urban entrepreneurialism" to describe the transformation of the public sector from its role as welfare provider to that of an entrepreneurship-booster (also known as "growth 
machine"), in pursuit of wealth and growth (Molotch, 1976). Such transformation goes hand in hand with other economic processes, especially the decline of Fordist organization of work, replaced thus by the logic of "flexible accumulation" (Harvey, 1989a). As these spatial practices were integrated into the logic of neo-capitalism, the dimension of space also - as class, gender and race - becomes a dimension of social inequality and contributed to the configuration of social inequalities (Harvey, 1989b). The second approach, that of the "global cities" theory proposed by Saskia Sassen (1994), depicts the polarization of wealth both between and within cities: on one hand, the globalized financial network, as well as the capital flux circulating among particular cities, divides urban agglomerations by different scales, pitting cities against one another in the competition to attract capital and to become more "global." On the other hand, within these global cities, the polarization both of sectors participating in globalized activities and also of those providing "non-global" services is also inscribed in the cities' spatial configuration, creating discrepancies between areas of concentrated globalized economic activities and those occupied by sectors with less value. Finally, the third approach draws attention to those cities and lands "left behind" by economic globalization. The diminishment of industrial infrastructure, and of working-class stability, raises the issues of urban shrinkage and the necessity for urban renewal or regeneration (Fol et Cunningham-Sabot, 2010), as well as the matter of gentrification processes observed in more and more post-industrial cities (Authier \& Bidou-Zachariasen, 2008), provoking debates about spatial justice and aesthetic norms that reproduce class distinctions by way of urban spatial division (Zukin, 1993).

3 The studies cited above have focused mainly on the urban trajectories of cases in advanced economies; however, the globalization processes of other sectors, as well as the experiences of other, "non-Fordist" types of cities, remains unknown. This article aims to extend the literature by focusing on a different case: the spatial consequences of a low-end process of economic globalization, represented here by the circulation of "made-in-China" products in a post-socialist city. As indicated by Ferenčuhová and Gentile (2016), the experience of urban transformation in the post-Soviet city is an under-studied subject, whereas such cases can contribute to the understanding of spatial consequences of neo-liberal development. This article thus proposes to analyze the creation of made-in-China trading routes to Central and Eastern Europe (CEE), and how the formation of such trading routes of wholesale commerce - namely the commerce inter-enterprises, the distribution of commodities from the middleman to professional clients who will re-sell the products to consumer (Pardo \& Paché, 2015) influenced urban transformation at the local scale.

4 My analysis is based on the materials collected through fieldwork on two occasions: a one-month fieldwork in Budapest (October 2017) to visit the market and to interview Chinese traders of varying generations, and a second fieldwork of two weeks (in June 2018) to complete the material and to conduct an interview with the local district governor. After a presentation of the context of the Chinese traders' arrival in Budapest, we will elaborate on the process of urban transformation within Budapest through three stages. 


\section{Budapest: from the industrial capital to trading hub in CEE region}

5 Modern Budapest was established in 1853, through the amalgamation of three cities on the two sides of Danube River: Buda, Pest and Obuda. As Ivan Tosics has emphasized, the biggest difference between socialist cities and non-socialist cities lies in their respective patterns of development: compared to cities in capitalist countries, the urban organization of socialist cities is much more dominated by policy-oriented urban planning. As a result, unlike the clear downtown-suburb division often found in capitalist cities, socialist cities ar estructured differently, and may have an industrial zone right in the city center (Tosics, 2006). Budapest is a perfect illustration of such a model. In the name of development, Budapest has become one of the most industrialized cities in the CEE region: Between 1950 and 1970, the city experienced extensive industrialization. In 1985, the total size of Budapest's industrial area was approximately 4600 hectares, or 8.6 percent of the city's territory (Kiss, 2007). Most of the industrial sites are concentrated in the Pest side (ibid.).

The implementation of a market economy in 1990 has altered the landscape. As one of the pioneers among CEE countries in promoting economic reform, Hungary has since 1972 allowed the establishment of private joint-venture enterprises. The marketization of the territory, since 1989, has accelerated the process of deindustrialization: between 1990 to 2004, the total employment within industrial sectors decreased more than half, falling from 277,851 to 117,017 employed workers, whereas employment in service sector rose from 360,953 to 649,953 (Kiss, 2007). As a result, the surface of industrial areas in the city have shrunk by about 40 percent. The industrial sectors mostly affected those within mining, metallurgy, textiles, and some branches of machine manufacturing (Kiss, 2009).

Chinese immigrants arrived in Budapest in this context. In 1989, as Hungary entered into the market economy, it also implemented a new policy making visas available to Chinese citizens. In the wake of the Tiananmen event - a nation-wide mobilization for regime change, violently suppressed by the Chinese Communist Party in spring 1989 citizens of various social classes, ranging from rural residents to civil servants and intellectuals, were attracted by the possibility of leaving China. An estimated 40,000 Chinese migrants arrived in Hungary between 1989 and 1992, which obliged the government to impose a policy of visas (Szabo, 2009). In Hungary and other postsocialist countries, where everyday consumer goods were not always readily available, inexpensive products manufactured in China satisfied an urgent need, and were thus popular. Those who imported and sold these goods met with success. A commercial route emerged as rural migrants (mostly from Zhejiang and Fujian) formed a network of "Chinese markets" all over Russia. From the capital to the village, Chinese vendors become the minority middlemen who provided consumers with inexpensive household products produced in China (Nyiri, 2011). The expansion of the Chinese wholesale community in Hungary also motivated the traders to delocalize to other Central European countries: some left Hungary because of the saturation of the niche there; others were disappointed by Hungary's arbitrary taxation policy ${ }^{1}$; a few successful entrepreneurs sought to establish branches in emergent markets such as Serbia and Bosnia-Herzegovina. 
8 Finally, China's entry into the World Trade Organization in 2001 made the importation of goods from China less expensive than it had been in the past. The practice of crossborder trade has become less necessary. Some traders establish their own factories in China and transport goods directly to Europe; others depend on contacts there. Another striking development has been Italy's emergence as a European workshop: as the cost of transportation and wages in China rises, the Chinese communities in Prato who have since the late 1990s revitalized the Italian city's once-thriving textile industry (Ceccagano, 2017) - became an alternative for traders in Europe. Several of our informants in Hungary have affirmed that they placed orders from Italy. The "made-inItaly" label is today omnipresent in these wholesale centers.

Our brief review describes how Chinese migrants arriving in Europe since 1978 have transformed Europe's light industrial sector. In the following section, we will thus focus on how the expansion of the Chinese market affects urban change in Budapest; and, specifically, how the development of the market - created in response to consumer needs within the CEE region - went hand in hand with the de-collectivization of the industrial infrastructure, turning the former factory into a showroom and place for the consumption of exotic goods.

\section{Renovating the industrial wasteland: the expansion of the Chinese wholesale market in three steps}

The Chinese marketplaces in Budapest are situated in the $8^{\text {th }}$ and $10^{\text {th }}$, districts, in a vast zone historically occupied by industrial buildings. The city of Budapest has confronted the persisting issue of population loss and urban shrinkage since its transition from socialism in 1989, and continually seeks strategies to combat the problem (Beliczay, 2009). However, the two districts considered here have distinct roles and strategies in the process of urban regeneration in Budapest. The $8^{\text {th }}$ district, Józsefváros, is an area historically stigmatized due to its degraded housing, concentration of poverty and large population of immigrants and working-class residents (Czirfusz et al., 2015). Therefore, Józsefváros has become a target area for post-socialist urban renovation and gentrification efforts, due to its stigma as a "local Harlem" and its proximity to the city center - factors that attract capital investment as well as attempts to "close the rent gap" (Czirfusz et al., 2015). By contrast, the $10^{\text {th }}$ district, Kobanya, is far less affected by such urban regeneration projects because of its distance from the inner-city center. Situated at the intermediate zone of Budapest, between the outskirts and the inner city, the Kobanya District is historically an industrial neighborhood and still proudly maintains its identity as such. Even today, the taxation of industries still plays the biggest role in the district's financial revenue ${ }^{2}$.

Since 1989, three different Chinese markets were established: "Four Tigers Markets" and "Eurosquare" in the $8^{\text {th }}$ district, and the "Monori Center" in the $10^{\text {th }}$ district. The evolution of these marketplaces reveals different stages in the development of migrant communities, but also these communities' relationship with local authorities, and their strategic response to other, competitive actors in the neighborhood. It is thus a telling case in understanding the process of land competition and urban requalification in different parts of Budapest. 


\section{"Four Tigers Market" in the former Ganz Works}

Figure 1. Post-Socialist Reconversion in Jozsefvaros district in Budapest

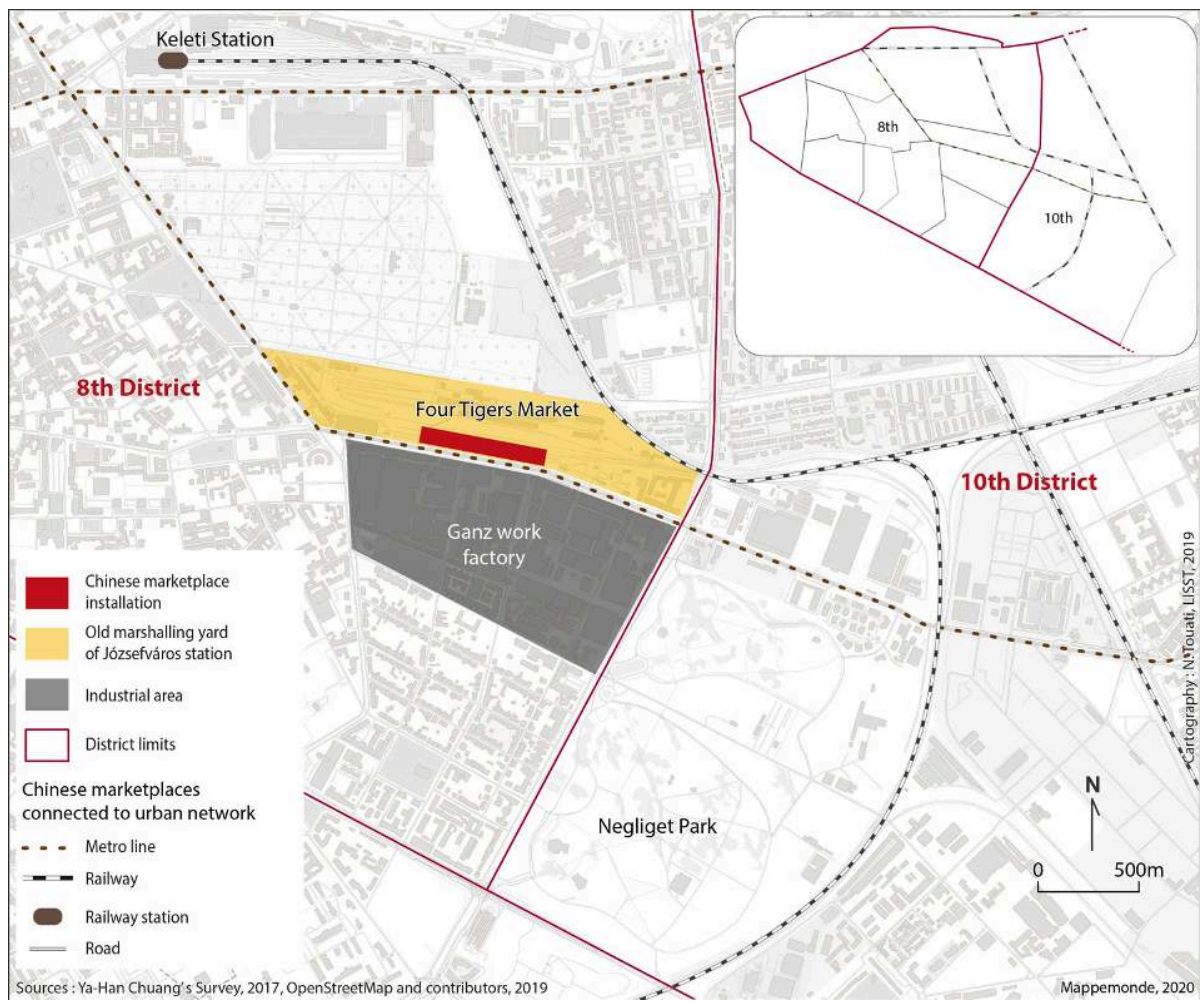

Chinese marketplaces in abandoned industrial area (1993-2000)

The first step of this urban transformation occurred via the privatization of the ancient "Ganz Works" building, formerly belonging to the Hungarian national railway company, which was transformed into "Four Tigers Market" (Jozsefvaros Kinai Piac in Hungarian) and inaugurated in 1994 (figure 1). Ganz Works was founded in 1844 and was controlled by various foreign investors before being nationalized by the Hungarian government a hundred years later. Following Hungary's regime change in 1989, the company was privatized in 1991 and began entering into joint ventures with international investment sources. Since then, a large part of the company's land and factory buildings were transferred into private ownership, followed by a process of employee lay-offs which began in $1995^{3}$.

Before 1993, most Chinese vendors circulated in different areas of the cities where they worked - setting up shop, for example, in underpasses - to sell cheap clothes in a casual and often illegal way. Some larger vendors were established in other, more formal markets, such as the "Russian market" in the $11^{\text {th }}$ district of Budapest (Szabo, 2009). In 1993, following the closure of several markets in the outskirts of Budapest, a Hungarian real-estate company leased the former Ganz Works factories and constructed the Four Tigers Market. A great number of Chinese wholesalers thus settled to the area, alongside traders of other nationalities (Vietnamese, Turkish, Egyptian, Ukrainian, Romanians, etc.). In order to highlight the presence of Asian traders, the manager chose the name "Four Tigers Market," which harkens to the "Four Asian Tigers" model of economic growth (figure 2). 
Figure 2. Former Ganz Works transformed into "Four Tigers Market"

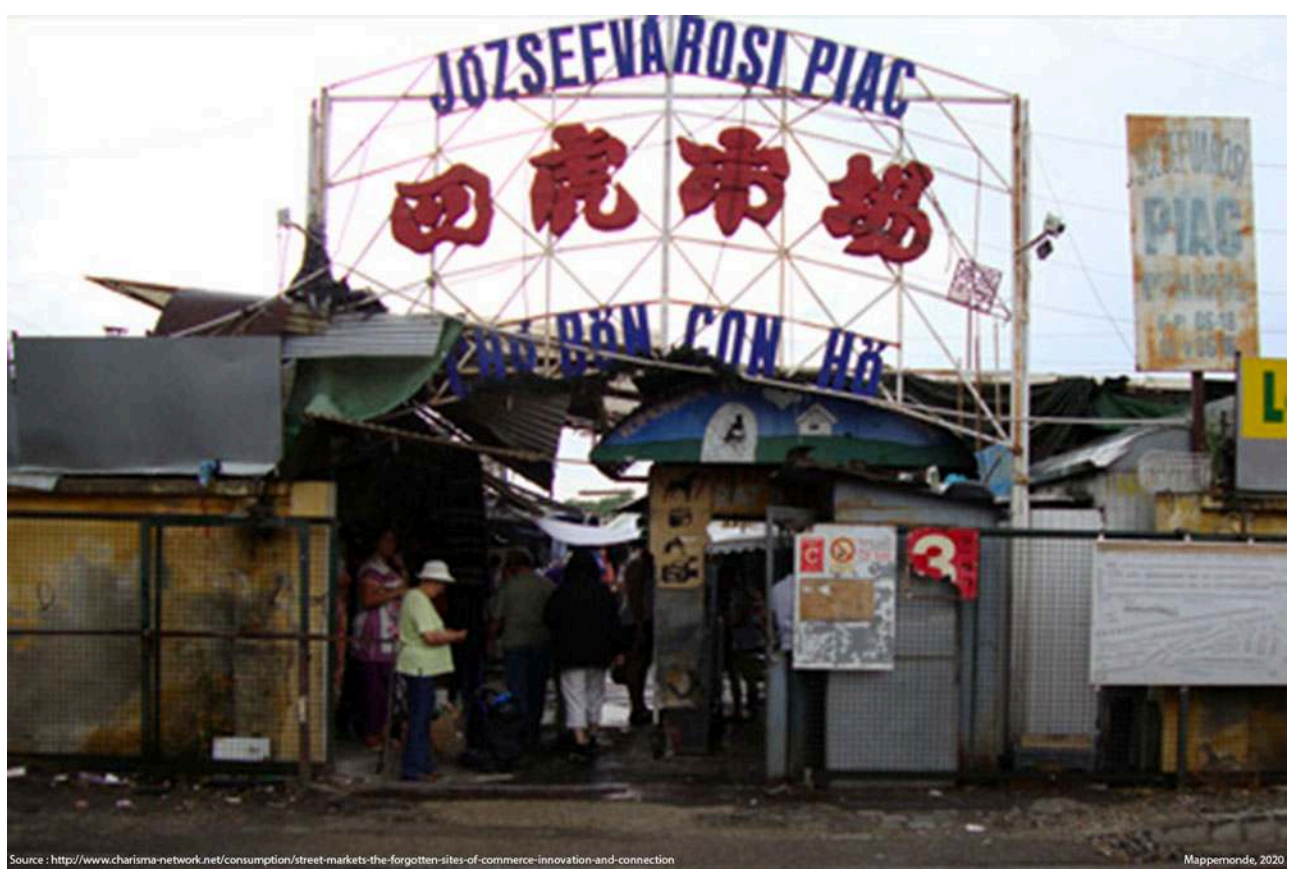

Source: http://www.charisma-network.net/consumption/street-markets-the-forgotten-sites-ofcommerce-innovation-and-connection

As the first platform of circulation for the entire central-eastern European region, the Four Tigers Market attracted clients from all over the area. Many Chinese traders described the 1990s as a "golden era". Some of my informants recall the period as one when "money was like the sands on the beach"." The opportunities for enrichment and affluence within in a primitive capitalist market attracted not only traders from China, but even overseas Chinese who settled in other countries. Such is the trajectory of Mrs Lin, owner of a chain of supermarkets and an Asian food trading company in Hungary. Originally from Qingtian, Mrs. Lin owned several Asian supermarkets in Brooklyn; in 1995, she came to Budapest to visit a friend, who was also from Qingtian. According to Mrs. Lin, she discovered that her friend's daily earnings equaled her own weekly income in New York. This motivated her to join international trading by ordering two containers from China of ready-to-wear clothing to sell at the Four Tigers Market. However, her first attempts at breaking into the market were unsuccessful: Lacking knowledge of the ready-to-wear market, Mrs. Lin was misled by providers in China, who sold her low-quality products at a high price. After several month's difficulties in selling her products, she almost went bankrupt. It was thanks to her investment in the sector which she knows best - the food industry - that Mrs. Lin finally profited enough and, later, created the biggest franchise of Asian food supermarket in Hungary. Today, her business is situated in several Central European countries ranging from Austria to Romania.

15 The development of trading routes between China and Europe also placed Budapest in the path of counterfeit products. As Hungary is centrally situated in Europe, the network of Zhejiang migrant entrepreneurs also allows made-in-China counterfeit luxury goods to circulate via the diaspora network. As recalled by a restaurant owner from Qingtian who settled in Budapest in 1987, "In that era, our family members may 
have driven from Italy or Spain to Budapest and filled their cars with counterfeit products to take back to their country". In the meantime, as with the "road of jeans" between Yiwu and Cairo (Pliez, 2007), the Chinese merchants in Europe also constituted their "road of Nike" through central Europe. Mr. Wan, the CEO of a shoe company in Budapest, describes the banality of counterfeiting during this period: "At that time, many came and asked us to put the logo of famous brands on the products. Many of my friends have done that. I wanted to create my brand and thus resisted the temptation, but many of my acquaintances considered this is irrational." ${ }^{6}$ However, whereas such practices - typical of informal economies - explains the rapid accumulation of profits, they also led to intensified police control and criticism favorable to the market's shutdown.

16 As the wholesale business of made-in-China products created considerable inflows of commodities, workers, and consumers, the entire Józsefváros district also underwent a process of gentrification, aimed at attracting more foreign capital to boost the realestate market. The process was launched by the district government eager to get rid of the area's "Local Harlem" image (Scott \& Sohn, 2018). The most representative example of their efforts is the "Corvin Promenade Project": Situated along the border of the inner-city center, this neighborhood - once composed of degraded buildings - is today occupied by a shopping center, casino and high-end residential building designed for tourists and elites (Keresztély \& Scott, 2012). There is, however, some tension between the actors of gentrification and those of the market: the concentration of foreign traders and immigrant workers in the market tends to reinforce the "ghetto" stigma surrounding the district, and appears increasingly incompatible with the new image that developers wish to project. Accordingly, since the mid-2000s, the government of the $8^{\text {th }}$ district has frequently expressed their intention to close the market. In 2014, the government announced their decision to close the Four Tigers Market in order to establish an international football stadium. ${ }^{7}$

17 The pressure to close the market drove the Chinese entrepreneurs to target other available properties. Thus, emerged two market spaces in the surrounding area: the "Eurosquare" and the "Monori Center."

\section{Eurosquare: migrant entrepreneurs transforming former Ganz Works factory buildings into showrooms}

The second stage of the Chinese market expansion was characterized by the emergence of Chinese entrepreneurs as real-estate actors. As the Four Tigers Market expanded, some wholesalers began investing in the vacant Ganz Works properties on the other side of the avenue. Those investors turned out to be the primary actors of the new market, named "Eurosquare" today (figure 3). 
Figure 3. Post-Socialist Reconversion in Jozefvaros District in Budapest

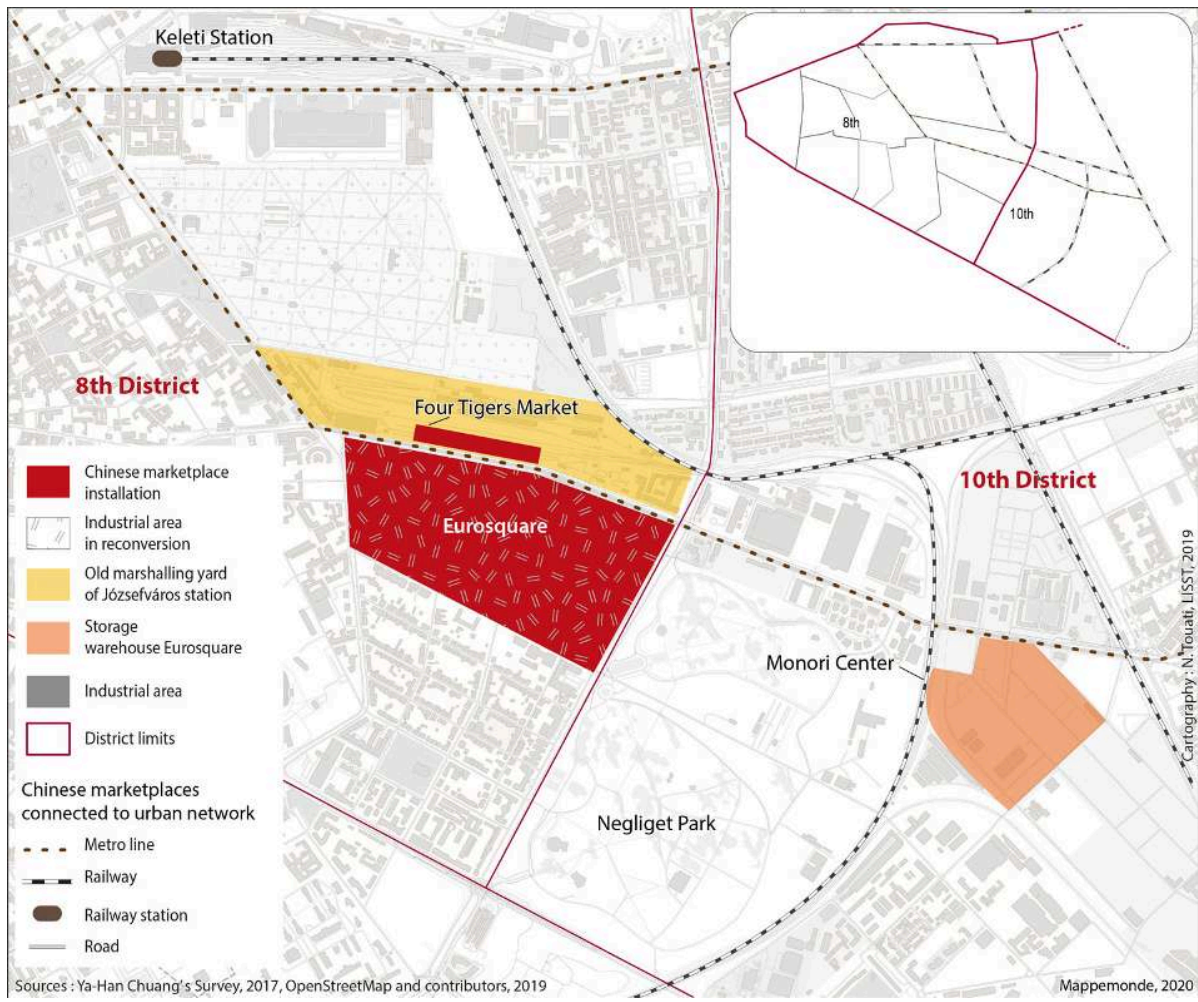

From Industrial Zones to Organised Showrooms.

19 Since 1991, the Ganz Company has transformed into a semi-public enterprise, attracting a diverse array of buyers to purchase the company's vacant spaces and transform them into storage facilities. It is estimated that the factory and office properties at Ganz belong to at least 140 owners of at least 20 different nationalities. As the threat of the Four Tigers Market's closure became tangible, some entrepreneurs had the idea to open a new market on the new, nearby site. In 2002, a part of the former Ganz Factory at 23-25 Kobanya was renamed "Eurosquare" (ouya guangchang), becoming the second Chinese market in the city (figures 4 and 5). 
Figure 4. "Welcome to Eurosquare" at the market's entrance

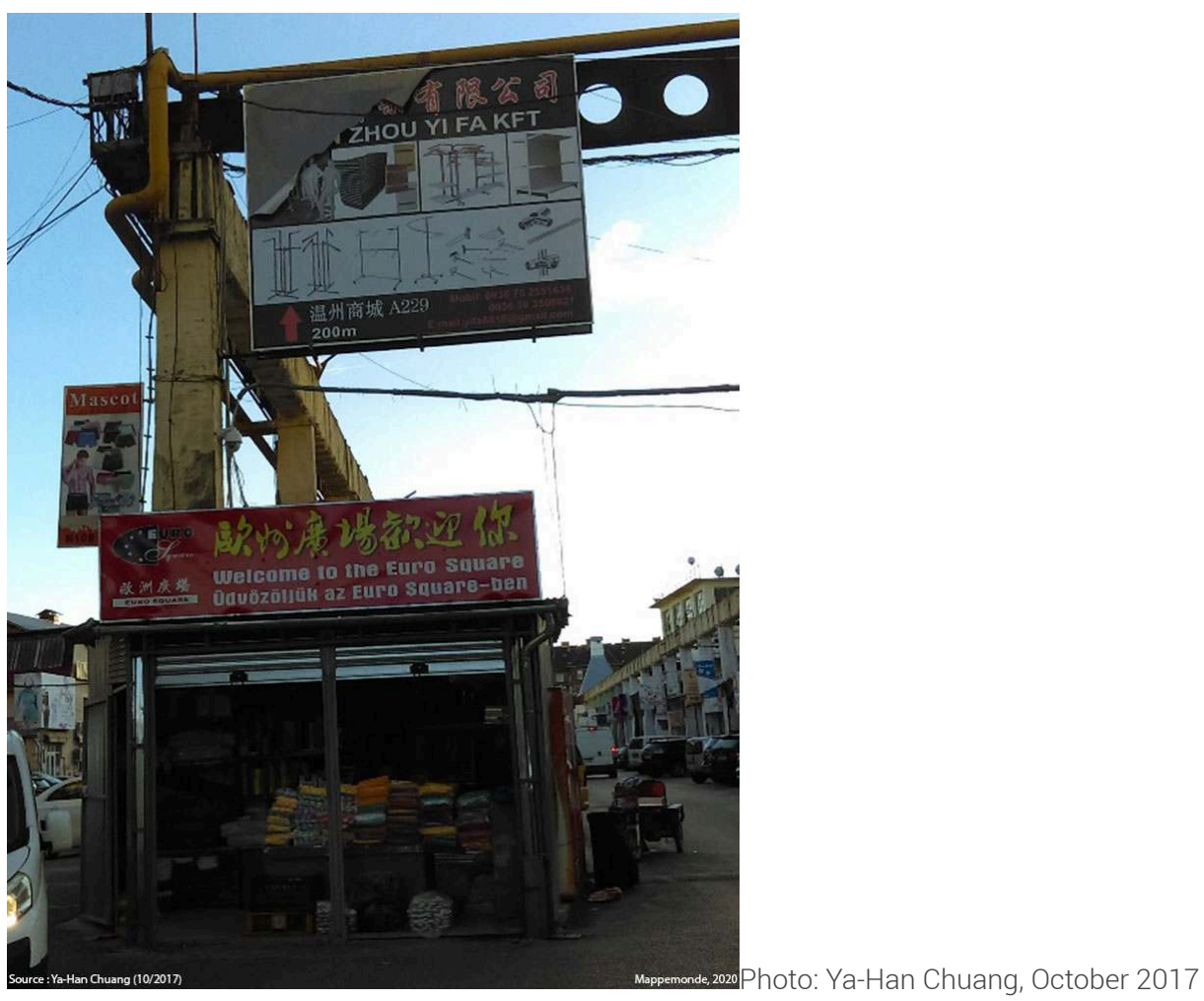

Figure 5. Ancient warehouse transformed into "Shanghai Street"

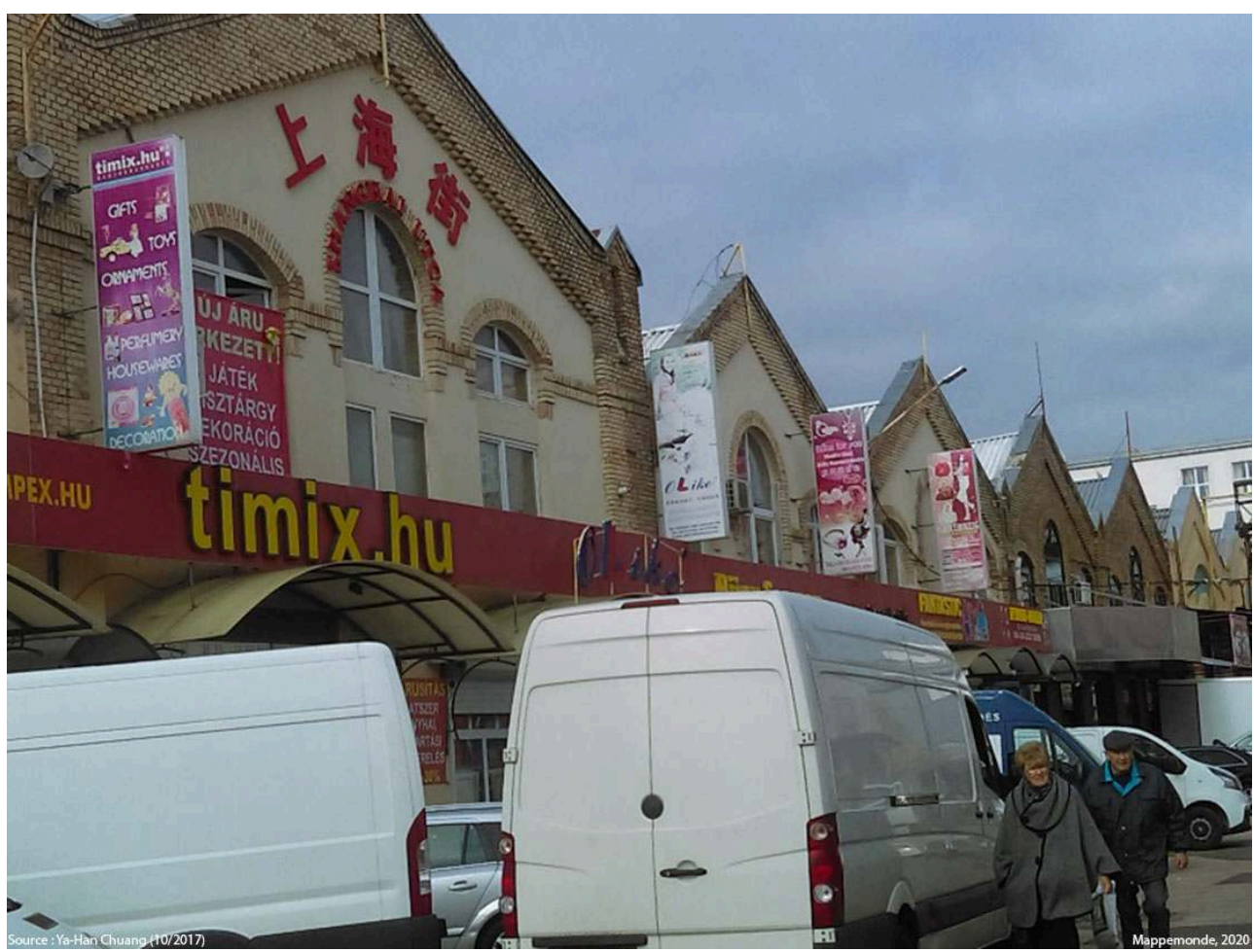

Photo: Ya-Han Chuang, October 2017

Although the Ganz site was divided and resold to shop owners of more than 20 nationalities, Chinese shop owners represented the most dominant group; this was 
largely due to the early investment of Mr. Ye, a man from Qingtian who arrived in Budapest in 1989, when the Hungarian border first opened. A longtime local servant, Ye started his career in Budapest as a trader in Four Tigers Market. Rapidly, he was entrusted by the owner of Four Tigers Market to take charge of a part of the rental contract, as well as communications with other Chinese traders. As his business grew, he bought several factory buildings at the Ganz site, facing the Four Tigers Market, using them for storage. Gradually, he divided these warehouses and tried to rent them as wholesale shops. As the pressure to close Four Tigers Market rose, an increasing number of Chinese wholesalers moved across the street to Eurosquare and became tenants of Mr. Ye. A considerable number of entrepreneurs there are also involved in retail or semi-wholesale trading, especially those arriving after 1995 and those who entered the market with less of a capital advantage.

21 For those who used to work at the Four Tigers Market, the memory of working in the cold of winter is the most common from that "golden era" of trading. Thus, the move away from Four Tigers Market represented for them a transition toward much improved working conditions: the new showroom spaces at Eurosquare are much larger than the stalls in Four Tigers Market and include the options of heating or air conditioning. Aside from Eurosquare's relatively organized appearance, the market seems to maintain the same ethnic division of work as that of the Four Tigers Market. During my fieldwork, as I was accompanied by another researcher who speaks Arabic, two Egyptian entrepreneurs attempted to prevent us from taking photos of their shop selling electronic products. Once the researcher started to communicate in Arabic, the entrepreneurs burst into laughter and amicably explained the reason of their reaction: they feared that we were journalists who will write article to diabolize the Eurosquare Market, as what happened often in the past. After the rough encounter, they explained that they have been working in the neighborhood for 25 years, right after the fall of the Berlin Wall. In other words, the disappearance of the Cold War boundary also transformed Budapest into a converging point of reading routes between the continents of Asia, Europe and Africa, attracting traders from Middle East and NorthAfrica countries to commute between Budapest and their home countries. Janus, a Hungarian man who used to work as a security guard at Four Tigers, describes:

22 "Everyone has found their place here. The Chinese do the wholesale, the Vietnamese retail, the Arabs (mainly from Egypt and Turkey) control the exchange of money. We have been fighting ${ }^{8}$ a lot in the 1990 s, and now we learn to live together calmly after those years."

23 Janus' narrative points out a division of work aligned with ethno-linguistic boundary. According to his vision, beneath the appearance of a trading hub seemingly dominated by Chinese merchants, Eurosquare is also host to a quintessential Muslim street market (Simone, 2007), similar to what can be found in Yiwu. (See the article of Olivier Pliez and Said Belgidoum, forthcoming). The arrival of "made-in-China" trading flows following the end of Cold War thus contribute to a configuration of "superdiversity" (Vertovec, 2007) within the market context.

24 On the other hand, the "Monori Center", which was inaugurated in 2006, symbolizes a new generation of modern showrooms. 


\section{"Monori Center": renovation and reconstruction of a new wholesale center in privatized factory buildings}

Figure 6. Post-Socialist Reconversion in Jozsefvaros district

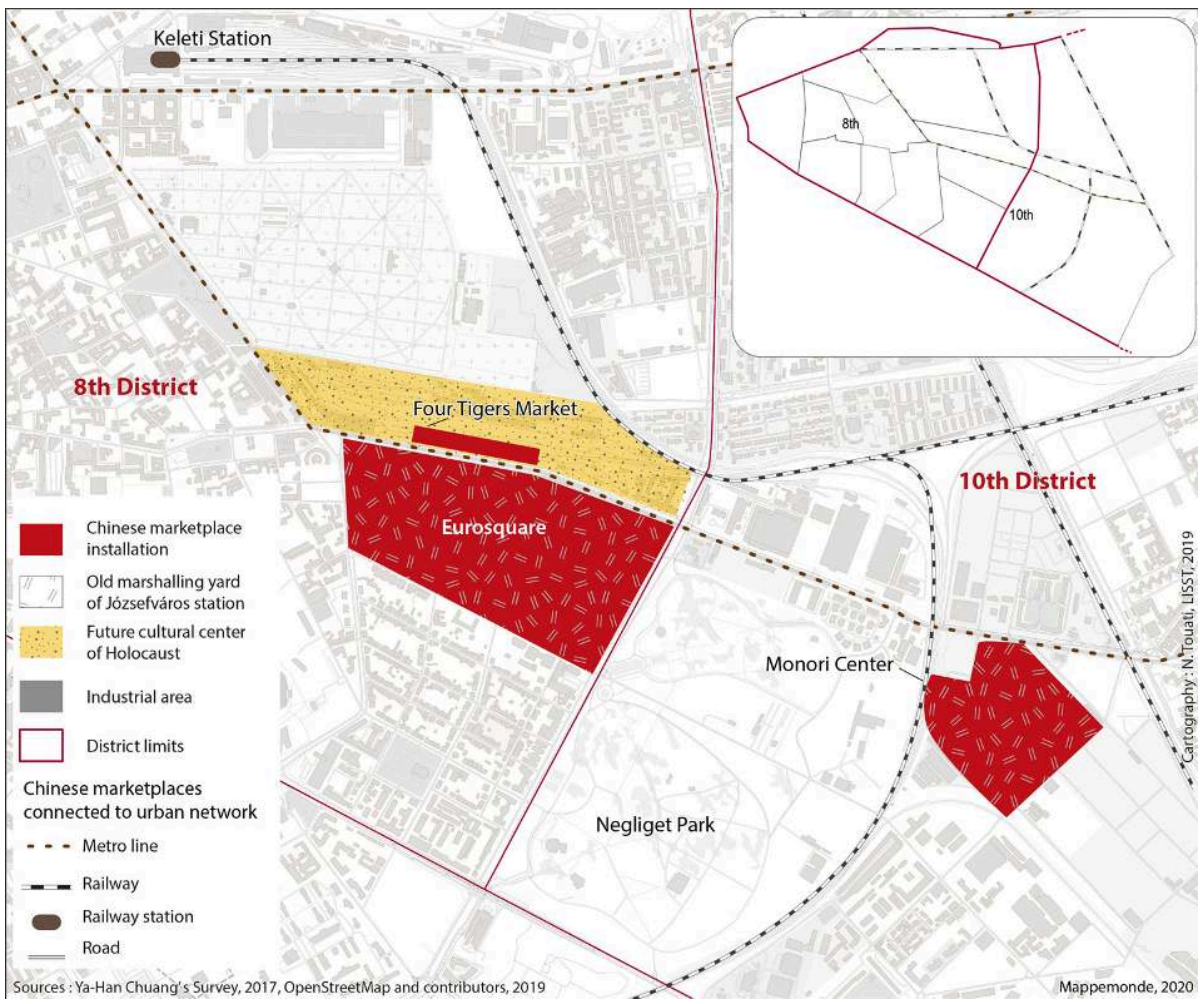

Relocation and Extension of Chinese Showrooms (2008-Today).

The third stage of the urban transformation in Budapest is characterized by the rehabilitation of abandoned industrial buildings, accompanied by the construction of new spaces dedicated to showrooms and other commercial activities (figure 6). This is the birth of the "Monori Center", a market space of 150,000 square meters located between Monori utca, Szállás utca, Jegenye utca, and Horog utca, in the Budapest's $10^{\text {th }}$ district (Kobanya). The market is named after the "Mono Street" traversing the area, which used to be occupied by various warehouses and publically owned factories. In the late 1990s, Mr. Song Wanjun, a trader from Henan at the Four Tigers Market, bought the land for use in storing his stock. Unlike Ye Jianxin, the owner of the Eurosquare market who chose to preserve the old Ganz structure, Song Wanjun dreamed of constructing a new facility designed to reflect the image of Budapest's Chinese community. Hence Mr. Song's choice to name the center "Tang ren jie" in Chinese, which literally means "Chinatown". He explains:

"In many western countries, the Chinatowns were conditioned by the historical buildings and were thus dirty and unorganized. Our 'Chinatown' was planned from the ground up and thus can approach Western and European standards, becoming a community for Chinese. ${ }^{10}$ "

According to this narrative, the market is not merely a place of work for Chinese traders, but also a representation of the Chinese migrant community in the eyes of the majority population. Driven by such ambition to construct a "Chinatown" from scratch, 
Mr. Song gradually transformed the surrounding area into a network of well-organized showrooms, by both renovating ancient factory buildings and constructing new showrooms (figure 7). Such operations not only provided higher rental values, but also revealed Mr. Song's intention to build a modernized Chinese market, distinct from the negatively perceived Four Tigers' Market by improving its esthetic presentation.

Figure 7. Old factory building in front of newly-constructed showroom of the Monori Center

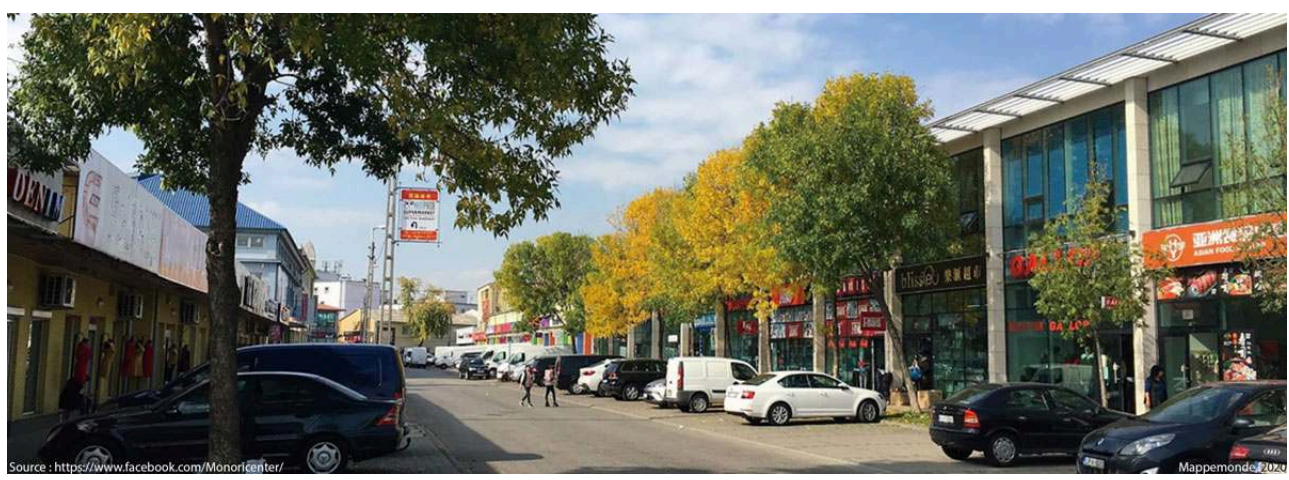

On the left: old buildings of ancient factory; on the right: newly-constructed showroom.

Source: the official Facebook website of Monori Center (https://www.facebook.com/Monoricenter/)

The Monori Center differs from Eurosquare in its architectural design, and also in the diversity of its commerce. In addition to a multitude of wholesale showrooms - textiles, shoes, children's clothes, fishing equipment, as well as "Italian Fashion" which refers to the textiles made by Chinese entrepreneurs in Italy, etc. ${ }^{11}$ - various commercial outlets for intra-community consumers can also be found here: supermarkets, restaurants, karaoke parlors, travel agencies, and bookshops. Situated around the edges of the showroom areas, various communitarian institutions (a church, a lawyers' office, a bilingual school for children) illustrate the social function of this discrete "Chinatown." Besides serving the consumption needs of the traders who work in the neighborhood and the Chinese residents living nearby, Song's choice also results from a structural factor: the economic crisis in Hungary in 2008. The global economic crisis in 2008 has severely damaged Hungarian economy, causing $17 \%$ depreciation of the Hungary Forint related to Euro and $6.7 \%$ of GDP decline; the volume of foreign directly investment in Hungary also fell almost 30 percent (Egedy, 2012). Due to the recession of Hungarian economy, numerous Chinese traders went bankrupt and opted to go back to China. The context of economic crisis has lowered the demand from Chinese traders to rent the showroom and urged the constructor like Mr. Song to innovate the usage of commercial space.

29 As a result, the initial, industry-led efforts toward urban regeneration, made during a period of post-socialist transition, now result in the possibility of cultural consumption. In the summertime, many native Hungarians come to Monori Center to enjoy the "Monori Night Market", which has become a regional tourist attraction. Featuring various restaurants and a large outdoor market, the Monori Center area represents - unlike its predecessors, wholesale markets generally cut off from residents - an attempt to serve as a venue for exotic cultural consumption, addressed to local consumers both Chinese and non-Chinese.

30 As Song puts it, we "want to construct a real Chinatown" ${ }^{12}$. He plans to build a residential site in the area, with 200 apartments. His intention to expand the Monori 
Center from a neighborhood of work to one that includes residential functions reflects the transformation of the Chinese ethnic economy on the European continent. One the one hand, the wholesale niche is almost saturated, reducing demand for showrooms and inviting the innovation of new land-use strategies ${ }^{13}$. On the other hand, in 2013, the Hungarian government announced a "Residency Bond Program" allowing non-EU citizens to acquire a permanent Hungarian residence permit by purchasing a state bond for 250,000 euros; at least 4,000 Chinese citizens are estimated to have done so $^{14}$. The new policy has led to a qualitative change for the Chinese population of Budapest, along with an increasing number of second-generation arrivals. Such a transformation - from economic migrants (traders and workers) to better-off, transnational, uppermiddle class residents - is mirrored by the dynamic commercial activity at Monori Center, and its new markets for cultural consumption.

\section{Epilogue: whose silk road?}

31 Our analysis thus describes the urban transformation on the margin of Budapest's urban center, resulting from the formation of an intercontinental trading route in the wake of socialist reform. As has been shown by the synthesis map (figure 8), through the years, as the commodity inflow increased to sustain expanding markets in the central-eastern European region, the markets also sought newly available lands and expanded to even more peripheral areas, where they adopted architectural forms deemed more compatible with the environment and more durable for the shop owners.

Figure 8. Different stages of post-socialist reconversion in the Józsefváros District in Budapest

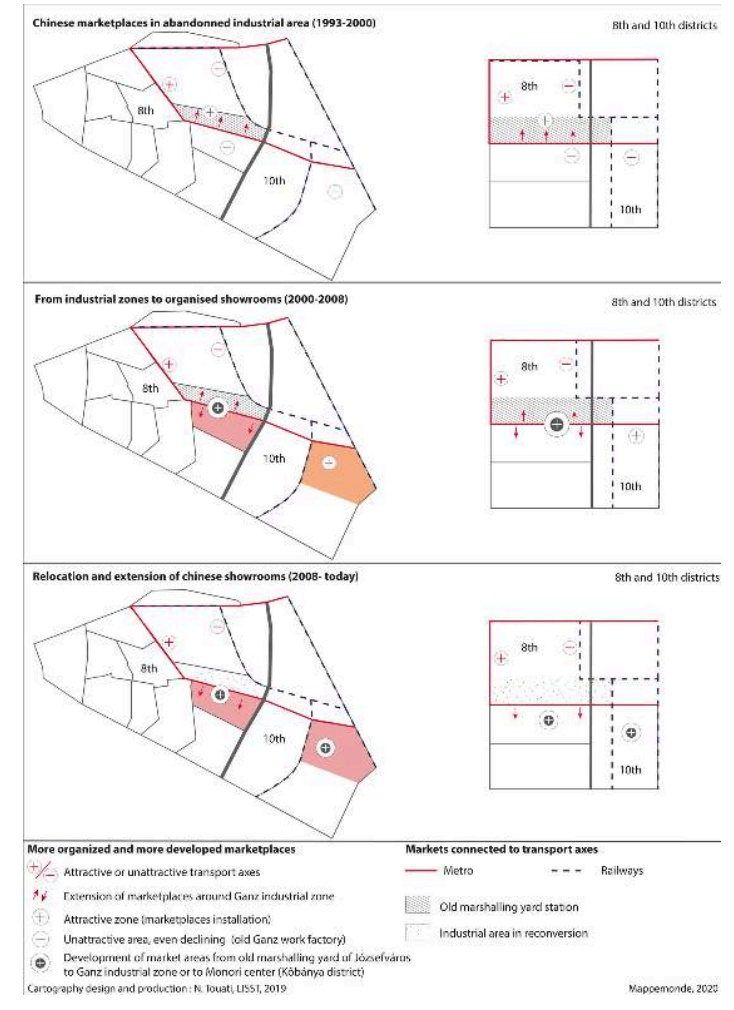

Unlike the "Corvin Promenade Project" - a state-led initiative to attract high-end, international investment to develop the city's tourism sector in the west end of the $8^{\text {th }}$ 
district - the evolution of "made-in-China" market spaces was a development fitting to the local population's needs. As such consumption needs grew, the Chinese traders evolved from purely economic actors to urban actors, participating themselves in the process of urban regeneration by recycling abandoned factory buildings and constructing new market spaces, and even new housing spaces. The dialectic between commodity flows and human mobilities, which arose through the circulation of "madein-China" products in Europe, thus represented very different and discrete trajectories in the context of post-socialist cities lacking urban planning policies. It also reveals an autonomous diaspora of migrants who arrived in the CEE region much earlier than the state-led "Belt and Road Initiative".

Such collective trajectories, representing "actually existing trade routes" (Marsden, 2016) underpinned by low-end globalization, undermine the narrative of "Belt and Road Initiative" as a state-led trading project. Two lines of inquiry may be productive for future research: theoretically, our study invites further analysis linking the transformation of human mobilities, commodity inflows and geographical development in the 1990s, between the collapse of communism and the formation of the EU common market. The central-eastern European region is undoubtedly a strategic area to investigate such transformation. In terms of empirical research, as the Chinese state triumphantly promotes its "Belt and Road" development initiative within the CEE region, it would be worthwhile to survey traders there, to explore to what extent these infrastructure changes affect their commercial practice. The results of such research will allow scholars to not only estimate the credibility of the "Belt and Road Initiative" narrative, but to also correlate the substantial economic and political dimensions of such a project.

\section{BIBLIOGRAPHY}

AUTHIER J.-Y., BIDOU-ZACHARIASEN C. (2008). « La gentrification urbaine ». Espaces et sociétés, $\mathrm{n}^{\circ}$ 132-133, p. 13-21.

BELICZAY E. (2009). “Urban regeneration in Budapest”. Study commissioned by the Institute for Transportation \& Development Policy (ITDP).

BELL D. (1973). The Coming of Post-Industrial Society: A Venture in Social Forecasting. New York : Basic Books.

CECCAGNO, A. (2017). City Making and Global Labor Regimes: Chinese Immigrants and Italy's Fast Fashion Industry. Springer.

CZIRFUSZ M., HORVÁTH V., JELINEK C., PÓSFAI Z., SZABÓ L. (2015). “Gentrification and Rescaling Urban Governance in Budapest-Józsefváros". Intersections. East European Journal of Society and Politics, vol. $1, \mathrm{n}^{\circ} 4$, p. 55-77.

EGEDY T. (2012). "The effects of global economic crisis in Hungary". Hungarian Geographical Bulletin, vol. 61, no 2, p. 155-173. 
FERENČUHOVÁ S., GENTILE M. (2016). “Introduction. Post-socialist cities and urban theory”. Eurasian Geography and Economics, vol. 57, $\mathrm{n}^{\circ}$ 4-5, p. 483-496.

FOL S., CUNNINGHAM-SABOT E. C. (2010). « Déclin urbain et Shrinking Cities : Une évaluation critique des approches de la décroissance urbaine ». Annales de géographie, $n^{\circ}$ 674-2010/4, p. 359-383).

HARVEY D. (1989a). The condition of postmodernity: an inquiry into the origins of cultural change.

Oxford : Blackwell.

HARVEY D. (1989b). "From managerialism to entrepreneurialism: the transformation in urban governance in late capitalism". Geografiska Annaler: Series B, Human Geography, vol. 71, nº 1, p. 3-17. KERESZTÉLY K., SCOTT J. W. (2012). “Urban regeneration in the post-socialist context: Budapest and the Search for a Social Dimension". European Planning Studies, vol. 20, n 7, p. 1111-1134.

KISS É. (2007). “The evolution of industrial areas in Budapest after 1989”. In STANILOV K. (éd.), The Post-Socialist City, Dordrecht : Springer, p. 147-170.

KISS É. (2009). "Major trends in the development of industrial areas of Budapest in the early 21st century". Hungarian geographical Bulletin, vol. 58, $\mathrm{n}^{\circ}$ 3, p. 163-180.

MARSDEN M. (2016). “Actually existing silk roads”. Journal of Eurasian Studies, vol. 8, nº 1, p. 22-30.

моLотсн Н. (1976). “The city as a growth machine: Toward a political economy of place”. American journal of sociology, vol. 82, $\mathrm{n}^{\circ}$ 22, p. 309-332.

NYÍRI P. (2011). “Chinese Entrepreneurs in Poor Countries: a Transnational 'Middleman Minority' and its Futures". Inter-Asia Cultural Studies, vol. 12, $\mathrm{n}^{\circ}$ 1, 145-153.

PARDO C., PACHÉ G. (2015). « Introduction générale ». In C. PARDO, éd., Commerce de gros, commerce inter-entreprises : Les enjeux de l'intermédiation, Caen : EMS éditions p. 11-20.

PLIEZ O. (2007). « Des jeans chinois dans les rues du Caire, ou les espaces discrets de la mondialisation ». Mappemonde, $\mathrm{n}^{\circ}$ 88(4-2007). En ligne : https://mappemonde-archive.mgm.fr/ num16/articles/res07404.html

SZABÓ M. (2009). Why Would We Need a Chinatown? The Case of Chinese Entrepreneurs in the Rust Belts of the 8th and 10th Districts of Budapest. Thèse, Budapest : Université d'Europe centrale, Département de sociologie et d'anthropologie sociale.

SASSEN S. (1994). Global city. New York, London, Tokyo. Princeton : Princeton University Press. SIMONE A. (2007). "The Muslim Street is Everywhere (and soon coming to a theater near you)". Geoforum, vol. 38, n 4, p. 593-596.

scotT J. W., SOHN C. (2018). "Place-making and the Bordering of Urban Space: Interpreting the Emergence of New Neighbourhoods in Berlin and Budapest”. European Urban and Regional Studies, vol. $26, \mathrm{n}^{\circ} 3$.

TOSICS I. (2006). "Spatial restructuring in post-socialist Budapest". In TSENKOVA S. ET NEDOVIC-BUDIC Z., dir., The Urban Mosaic of Post-Socialist Europe, Heidelberg : Physica-Verlag, p. 131-150.

VERTOVEC S. (2007). "Super-diversity and its implications". Ethnic and racial studies, vol. 30, $\mathrm{n}^{\circ}$ 6, p. $1024-1054$

XIANG B. (2005). “Transcending Boundaries. Zhejiangcun: the story of a migrant village in Beijing”. Perspectives chinoises, $\mathrm{n}^{\circ} 111$, p. 91-93.

ZUKIN S. (1993). Landscapes of power: from Detroit to Disney World. Univ of California Press.

ISBN 9780520082885 


\section{NOTES}

1. Interview 28 October 2018 with a wholesaler of shoes from Qingtian.

2. Interview with the deputy mayor of $10^{\mathrm{TH}}$ district, 07 June 2018. Accompanied by Linda Szabo.

3. Official website of Ganz Holding: http://www.ganz-holding.hu/index.php/en/the-past/198historical-review

4. Interview 20 November 2017 with a former employee of the company that owns the market.

5. Interview 08 November 2017 with the manager of an Asian food market who arrived in Budapest in 1995.

6. Interview, 01 May 2017.

7. Since then, the land has remained empty. The construction project was not realized, and some stakeholders in the Four Tigers Market consider the decision to close it as a result of political corruption or pure discrimination of immigrant traders. (Interview, 20 November 2017, with the former employee of Four Tigers Market).

8. Here, he describes the everyday interaction between ethnic groups working in Four Tigers Market. However, other Chinese interviewees indicated that the 1990s decade was indeed an era with frequent incidents of violence, both intra- and inter-community.

9. Interview, 20 November 2017

10. http://paper.people.com.cn/rmrbhwb/html/2008-10/23/content_123994.htm

11. See the official website for a complete list: http://www.monoricenter.hu/shop/

12. Interview ibid. (as footnote 4).

13. Various structural factors contribute to the phenomenon: the multiplication of wholesale markets in other European cities; the rising costs of importation from China due to increasing wages and the appreciation of Chinese currency.

14. The Hungarian government ended the program in 2016.

\section{ABSTRACTS}

This article highlights how the emergence of trading routes between China and Hungary after 1989 has contributed to the urban transformation of Budapest. Initiated by migrant entrepreneurs arriving in a new economic context, and in response to a lack of everyday household products, the Chinese traders' spatial practices have evolved through three stages: they started with the rehabilitation of contaminated land within deindustrialized areas; they continued by redistributing the lands' usage rights via an emerging community of property actors and tenants; finally, they constructed modern showrooms dedicated for use by the wholesale sector. While increasing the land value through real-estate operations and management, the entrepreneurs also sought to cope with the aesthetic norms of urban renewal policy. By analyzing their spatial practices through a longitudinal perspective of thirty years, the article contributes to the study of economic globalization and urban transformation via a rare example of post-socialist cities.

Cet article souligne comment l'émergence de routes commerciales entre la Chine et la Hongrie après 1989 a contribué à la transformation urbaine de Budapest. Initiées par des entrepreneurs migrants arrivant dans un nouveau contexte économique, et en réponse à un manque de produits ménagers quotidiens, les pratiques spatiales des commerçants chinois ont évolué en trois étapes : 
réhabilitation des friches industrielles dans les zones désindustrialisées ; redistribution des droits d'utilisation des terres via une communauté émergente d'acteurs immobiliers et de locataires; construction, enfin, d'espaces d'exposition modernes destinées au secteur du commerce de gros. Tout en augmentant la valeur des terrains grâce à au développement de l'activité économique et à la gestion immobilière, les entrepreneurs ont également cherché à répondre aux normes esthétiques de la politique de rénovation urbaine. En analysant leurs pratiques spatiales dans une perspective longitudinale de trente ans, l'article contribue à l'étude de la mondialisation économique et de la transformation urbaine à travers un exemple rare de villes postcommunistes.

Este artículo destaca cómo, a partir de 1989, la consolidación de la ruta comercial entre China y Hungría contribuyó a la transformación urbanística de Budapest. Iniciada por empresarios chinos, en un contexto económico con carencias en productos básicos para el hogar, ha supuesto prácticas espaciales que han evolucionado en tres etapas: rehabilitación de espacios abandonados en áreas desindustrializadas; redistribución de los derechos de los terrenos mediante una simbiosis de intereses entre propietarios locales y arrendatarios; y, finalmente, la construcción de nuevos espacios para el comercio mayorista. Estas operaciones han supuesto un aumento del precio y de los alquileres de los inmuebles e importantes transformaciones en la política de renovación urbana. A través de tres décadas de prácticas espaciales se pueden estudiar los efectos de la globalización en la transformación urbana de esta ciudad poscomunista.

\section{INDEX}

Palabras claves: diáspora china, Europa central y oriental, desindustrialización, renovación urbana, comercio mayorista

Subjects: Les routes de la soie existent déjà. Routes transnationales et places marchandes du made in China entre Asie Afrique et Europe

Mots-clés: diaspora chinoise, Europe Centrale et de l'Est, désindustrialisation, régénération urbaine, commerce de gros

Keywords: Chinese diaspora, Central Europe, deindustrialization, urban regeneration, wholesale

\section{AUTHOR}

\section{YA-HAN CHUANG}

Sociologue, post-doctorante, INED 